\title{
PENGGUNAAN LOGIKA FUZZY UNTUK MENINGKATKAN KUALITAS PELAYANAN DI PENGADILAN AGAMA KABUPATEN KEDIRI
}

\author{
Niska Shofia ${ }^{1}$, Siti Rochana ${ }^{2}$ \\ ${ }^{1,2}$ Universitas Nusantara PGRI Kediri \\ niskashofia@unpkediri.ac.id ${ }^{1}$, sitirochana@unpkediri.ac.id ${ }^{2}$
}

\begin{abstract}
ABSTRAK
Dalam rangka meningkatkan pelayanan di bidang hukum, Mahkamah Agung RI memerintahkan seluruh Lembaga Peradilan untuk menyediakan fasilitas meja informasi (information desk), termasuk di Pengadilan Agama Kabupaten Kediri. Keberhasilan instansi dalam memberikan pelayanan yang berkualitas dapat ditentukan dengan pendekatan service quality. Penelitian ini dilakukan dengan melakukan pengamatan dan pengumpulan data dari masyarakat yang datang dan mencari informasi di Pengadilan Agama Kabupaten Kediri. Tujuan dari penelitian adalah untuk mengetahui faktor-faktor yang perlu ditingkatkan dalam pelayanan yang diberikan oleh petugas meja informasi Pengadilan Agama Kabupaten Kediri untuk mencapai kepuasan masyarakat. Analisa yang dilakukan adalah menggunakan pendekatan metode fuzzy servqual (Service Quality) yang dibantu menggunakan aplikasi MATLAB.
\end{abstract}

Kata kunci: fuzzy, kualitas pelayanan, MATLAB

\begin{abstract}
In order to improve the services in the field of law, the Supreme Court has ordered all Judicial Institutions to provide information desk facilities, including in the Religious Courts of Kediri Regency. The success of agencies in providing quality services can be determined by the service quality approach. This research is conducted by observing and collecting data from the people who come and seek information in the Religious Court of Kediri Regency. The purpose of the research is to know the factors that need to be improved in the service provided by the information desk officer of the Religious Court of Kediri Regency to achieve community satisfaction. The analysis is using fuzzy servqual method (Service Quality) which is assisted using MATLAB application.
\end{abstract}

Keywords: fuzzy, quality of service, MATLAB

\section{PENDAHULUAN}

Mahkamah Agung telah melakukan 3 kebijakan sebagai salah satu bentuk pelayanan kepada masyarakat, yaitu : Akreditasi sertifikat ISO serta lomba inovasi pelayanan publik antar satuan kerja diseluruh Pengadilan di Indonesia. (Badan Peradilan Agama, 2011). Pengadilan sebagai benteng terakhir penegak hukum harus terus menerus memperbaiki sistem Pengadilan guna meningkatkan kepercayaan publik, salah satu wujud dari Badan peradilan yang Agung adalah Pengadilan yang berorientasi pada pelayanan publik yang prima. Oleh karena itu, 
Pengadilan Agama Kabupaten Kediri sebagai salah salah satu instansi yang termasuk dalam Badan Publik di bawah lingkup Mahkamah Agung Republik Indonesia, juga harus meningkatkan kualitas pelayanannya berdasarkan pada Peraturan Menteri Pendayagunaan Aparatur Negara dan Reformasi Birokrasi Nomor 16 tahun 2014 tentang Pedoman Survey Kepuasan Terhadap Penyelenggaraan Pelayanan Publik. Selain itu, sebagai badan publik penyedia jasa,juga harus mematuhi Pedoman pelayanan informasi yang diatur dalam Pasal 1 butir 3 Undang-undang Nomor 14 Tahun 2008 tentang Keterbukaan Informasi Publik dan Surat Keputusan Direktur Jenderal Badan Peradilan Agama Mahkamah Agung RI tentang Pedoman Pelayanan Meja Informasi Di Lingkungan Peradilan Agama. (Badan Peradilan Agama, 2011). Pelayanan yang diberikan pada Instansi Pengadilan Agama kabupaten Kediri meliputi, Pelayanan meja informasi, pelayanan akta cerai, pelayanan pendaftaran dan pelayanan pengaduan. (Pengadilan Agama Kabupaten Kediri, 2015). Pada penelitian ini yang dijadikan sebagai fokus atau titik utama oleh penulis adalah pelayanan pada bagian meja informasi.

Keberhasilan instansi dalam memberikan pelayanan yang berkualitas dapat ditentukan degan pendekatan service quality yang telah dikembangkan oleh Parasuraman, Berry dan Zenthaml (dalam Lupiyoadi, 2006). Service Quality adalah seberapa jauh perbedaan antara harapan dan kenyataan para pencari layanan atas layanan yang benar-benar mereka terima dengan layanan sesungguhnya yang mereka harapkan. Apabila layanan yang diterima sesuai dengan yang dihaapkan, maka kualitas layanan dipersepsikan baik dan memuaskan.Sebaliknya, jika layanan yang diterima lebih rendah daripada yang diharapkan, maka kualitas layanan dianggap buruk.(Tjiptono, 2005). Penelitian ini merupakan salah satu upaya yang dilakukan untuk mengetahui faktor-faktor yang perlu ditingkatkan dalam pelayanan kepada masyarakat dalam memperoleh informasi di Pengadilan, khususnya pada pelayanan meja informasi di Pengadilan Agama Kabupaten Kediri. Teknik analisa dilakukan menggunakan konsep logika fuzzy melalui program MATLAB. 


\section{METODE PENELITIAN}

Langkah-langkah yang dilakukan dalam peneltian ini meliputi melakukan identifikasi masalah yang akan diteliti. Selanjutnya adalah menyusun kuisioner untuk mendapatkan data. Kuisioner yang dibuat terdiri dari dua bagian, yaitu: kuisioner persepsi masyarakat dan kuisioner harapan masyarakat. Langkah selanjutnya adalah melakukan rekapitulasi, pengolahan dan analisis data. Data kuisioner yang diambil mencakup aspek-aspek: (Kotler, 2008)

1. Tangibles (bukti langsung), meliputi penampilan fisik, perlengkapan pegawai dan sarana komunikasi.

2. Reliability (keandalan), yaitu kemampuan memberikan pelayanan yang dijanjikan dengan segera, akurat dan memuaskan.

3. Responsiveness (daya tanggap), yaitu kesediaan para staf untuk membantu para pelanggan dan memberikan perhatian yang tepat.

4. Assurance (jaminan), merupakan pegawai yang sopan dan berpengetahuan luas yang memberikan rasa percaya serta keyakinan.

5. Emphaty (empati), mencakup kepedulian serta perhatian individual kepada para pengguna.

Selanjutnya dilakukan implementasi dan analisa Fuzzy Servqual dengan aturan-aturan (rules) yang sudah disusun menggunakan bantuan Matlab Fuzzy Logic ToolBox untuk dapat mengetahui faktor yang perlu ditingkatkan untuk mencapai kepuasan masyarakat terhadap pelayanan meja informasi.

\section{HASIL PENELITIAN DAN PEMBAHASAN}

Pengadilan Agama merupakan salah satu lembaga negara yang bergerak di bidang jasa, salah satu jasa yang diberikan adalah pelayanan informasi yakni pelayanan yang berkualitas dan bermutu yang memenuhi kepentingan masyarakat. Berdasarkan Surat Keputusan Direktur Jenderal Badan Peradilan Agama Mahkamah Agung RI Nomor 0017/DjA/SK/VII/2011 tentang Pedoman Pelayanan Meja Informasi Di Lingkungan Peradilan Agama, pengertian Informasi adalah keterangan, pernyataan, gagasan, dan tanda-tanda yang mengandung nilai, makna dan pesan, baik data, fakta maupun penjelasan yang dapat dilihat, didengar dan dibaca, disajikan dan diperoleh dalam berbagai kemasan dan format sesuai 
dengan perkembangan teknologi informasi dan komunikasi secara elektronik ataupun non elektronik. Informasi Pengadilan adalah informasi yang dihasilkan, disimpan, dikelola, dikirim, dan atau diterima oleh suatu Pengadilan yang berkaitan dengan penyelengaraan tugas dan fungsi pengadilan, baik yang berkaitan dengan penanganan perkara maupun yang berkaitan dengan pengelolaan organisasi pengadilan. (Badan Peradilan Agama, 2011)

Kualitas informasi ditentukan oleh beberapa faktor:

1. Keakuratan dan teruji kebenarannya

Informasi harus bebas dari kesalahan-kesalahan dan tidak menyesatkan.

2. Kesempurnaan Informasi

Informasi yang diberikan lengkap tanpa pengurangan, penambahan dan penggubahan.

3. Tepat Waktu

Informasi disajikan secara tepat waktu.

4. Relevansi

Informasi memiliki nilai manfaat yang tinggi.

5. Mudah dan Murah

Apabila cara dan biaya untuk memperoleh informasi sulit dan mahal, maka orang menjadi tidak berminat untuk memperolehnya atau akan mencari alternatif yang lain.

Jasa adalah kegiatan yang ditawarkan dari satu pihak kepihak lain, yang tidak berwujud dan tidak menghasilkan kepemilikan apapun untuk dapat memuaskan kebutuhan konsumen. (Puti, 2013). Tujuh Kriteria pokok untuk mengklasifikasikan jasa menurut Lovelock, Evans dan Berman (Tjiptono, 2005), yaitu:

1. Segmen Pasar

Berdasarkan segmen pasar, jasa dibedakan menjadi jasa konsumen akhir dan jasa kepada konsumen organisasi.

2. Tingkat keberwujudan

Jasa dibedakan menjadi tiga macam: Rented Good Service (Konsumen menggunakan dan menyewa produk tertentu berdasarkan tarif dan jangka waktu tertentu), Owned Good Service (produk yang dimiliki konsumen direparasi, 


\section{Penggunaan Logika Fuzzy untuk Meningkatkan Kualitas Pelayanan di Pengadilan Agama Kab. Kediri}

dikembangkan atuau ditingkatkan oleh perusahaan jasa), Non Goods Service (bersifat tidak berbentu yang ditawarkan kepada konsumen)

3. Keterampilan penyedia jasa

Terdiri dari 2 macam, Professional Service dan Non Professional Service.

4. Tujuan organisasi jasa

Berdasarkan tujuan organisasi dibedakan menjadi Commercial Service dan Non Profit Service.

5. Regulasi

Dibagi menjadi Regulated Service dan Non Regulated Service.

6. Tingkat intensitas karyawan

Dibedakan dalam Equipment Based Service dan People Based Service.

7. Tingkat kontak penyedia jasa dan pelanggan

Dibagi menjadi High Contact Service (Universitas, Bank, Dokter), dan Low

Contact Service. Keterampilan interpersonal karyawan harus diperhatikan, seperti keramahan.

Keberhasilan instansi dalam memberikan pelayanan yang berkualitas dapat ditentukan dengan pendekatan service quality yang telah dikembangkan oleh Parasuraman, Berry dan Zenthaml (dalam Lupiyoadi, 2006). Service Quality adalah seberpa jauh perbedaan antra harapan dan kenyataan para pencari layanan atas layanan yang benar-benar mereka terima dengan layanan sesungguhnya yang mereka harapkan. Apabila layanan yang diterima sesuai dengan yang dihaapkan, maka kualitas layanan dipersepsikan baik dan memuaskan. Sebaliknya, jika layanan yang diterima lebih rendah daripada yang diharapkan, maka kualitas layanan dianggap buruk (Tjiptono, 2005).

Kuisioner persepsi dan harapan pelanggan ini diberikan kepada responden yaitu para pengguna jasa pelayanan meja informasi yang datang langsung untuk mencari informasi di Pengadilan Agama Kabupaten Kediri. Penelitian ini menggunakan Kuisioner yang bersifat tertutup. Kuisioner yang dibuat terdiri dari 19 pertanyaan yang disusun berdasarkan kategori objek servqual yaitu untuk objek Reliability terdiri dari 4 pertanyaan, Tangible terdiri dari 4 pertanyaan, Responsiveness terdiri dari 4 pertanyaan, Assurance terdiri dari 4 pertanyaan dan 
Emphaty teriri dari 3. pertanyaan. Tabel berikut menunjukkan secara rinci pertanyaan kuisioner dan kategorinya:

Tabel 1. Pertanyaan Kuisioner dan Kategorinya

\begin{tabular}{|c|c|l|}
\hline $\begin{array}{c}\text { No } \\
\text { Kuisioner }\end{array}$ & Dimensi Servqual & \multicolumn{1}{|c|}{ Uraian } \\
\hline 1 & $\begin{array}{c}\text { Tangiable } \\
\text { (BuktiFisik) }\end{array}$ & $\begin{array}{l}\text { Meliputi Penampilan gedung } \\
\text { kantor, ruang tunggu bagian } \\
\text { informasi Pengadilan dan } \\
\text { petugasnya. }\end{array}$ \\
\hline 2 & $\begin{array}{l}\text { Reliabilitas } \\
\text { (Keandalan) }\end{array}$ & $\begin{array}{l}\text { Meliputi Fasilitas yang dimiliki, } \\
\text { Informasi yang diberikan dan } \\
\text { keandalan petugas informasi } \\
\text { Pengadilan. pan }\end{array}$ \\
\hline 3 & $\begin{array}{l}\text { Responsiveness } \\
\text { (DayaTanggap) }\end{array}$ & $\begin{array}{l}\text { Meliputi respon atau kesediaan dan } \\
\text { ketanggapan petugas informasi } \\
\text { terhadap masyarakat. }\end{array}$ \\
\hline 4 & $\begin{array}{l}\text { Assurance } \\
\text { (Jaminan) }\end{array}$ & $\begin{array}{l}\text { Meliputi waktu pelayanan yang } \\
\text { diberikan dan keakuratan informasi } \\
\text { yang diberikan oleh petugas } \\
\text { Pengadilan kepada masyarakat }\end{array}$ \\
\hline 5 & $\begin{array}{l}\text { Empathy } \\
\text { (Empati) }\end{array}$ & $\begin{array}{l}\text { Meliputi perhatian yang } \\
\text { diberikanPetugas/ Pegawai kepada } \\
\text { masyarakat pencari informasi }\end{array}$ \\
\hline
\end{tabular}

\section{Pengolahan Fuzzy Service Quality}

Pada jawaban yang diperoleh terhadap pertanyaan-pertanyaan SERVQUAL yang diajukan melalui kuisioner tersebut akan dikelompokan berdasar dua kategori, yaitu kategori ekspetasi/ harapan dan persepsi pelanggan. Jawaban terhadap pertanyaan tersebut akan dinilai berdasarkan skala likert 5 poin. (Harto, 2005). Selanjutnya jawaban yang diperoleh akan diberi nilai dengan cara pembobotan seperti dibawah ini:

Tabel 2. Pembobotan Jawaban Kuisioner

\begin{tabular}{|l|l|c|}
\hline \multicolumn{1}{|c|}{ KATEGORI } & \multicolumn{1}{c|}{ JAWABAN } & BOBOT \\
\hline \multirow{3}{*}{ EKSPEKTASI/ } & Sangat Penting (SP) & 5 \\
\cline { 2 - 3 } & Penting (P) & 4 \\
\cline { 2 - 3 } & Cukup Penting (CP) & 3 \\
\cline { 2 - 3 } & Tidak Penting (TP) & 2 \\
\cline { 2 - 3 } & Sangat Tidak Penting (STP) & 1 \\
\hline PERSEPSI/ & Sangat Puas (SP) & 4 \\
\cline { 2 - 3 } KENYATAAN & Puas (P) & 4 \\
\hline
\end{tabular}


Penggunaan Logika Fuzzy untuk Meningkatkan Kualitas Pelayanan di Pengadilan Agama Kab. Kediri

\begin{tabular}{|l|l|c|}
\hline KATEGORI & \multicolumn{1}{|c|}{ JAWABAN } & BOBOT \\
\hline \multirow{4}{*}{} & Cukup Puas (CP) & 3 \\
\cline { 2 - 3 } & Tidak Puas (TP) & 2 \\
\cline { 2 - 3 } & Sangat Tidak Puas (STP) & 1 \\
\hline
\end{tabular}

Pertanyaan-pertanyaan yang diajukan dalam kuisioner dimaksudkan untuk mengetahui seberapa besar penilaian masyarakat terhadap kinerja dan pelayanan meja informasi yang diberikan selama ini.

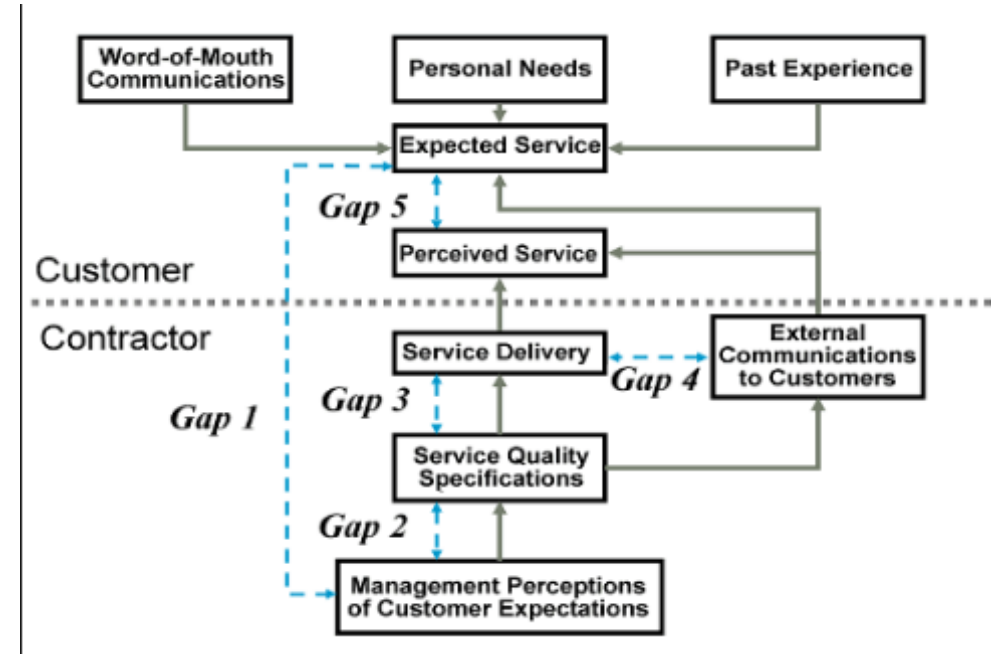

Gambar 1. Gap Model

Berdasarkan gaps models of service quality (Parasuraman, 1985) dari lima Gap yang memberikan dampak terhadap kualitas pelayanan adalah Gap 5, yaitu kesenjangan antara persepsi dan ekspektasi masyarakat mengenai kualitas pelayanan. Jika persepsi dan ekspektasi masyarakat terbukti sama dan bahkan persepsi lebih baik dari ekspektasi maka instansi akan mendapat citra dan dampak positif, demikian pula sebaliknya. (Harto, 2005).

Dengan menggunakan pengolahan data pada metode SERVQUAL, didapat hasil perhitungan bahwa dimensi yang memiliki nilai Gap terkecil adalah dimensi tangiabel (bukti fisik) Reliabilitas (keandalan), dan assurance (jaminan) yaitu sebesar 0 (nol), artinya petugas pada pelayanan meja informasi pengadilan telah memberikan pelayanan yang baik sesuai dengan harapan para masyarakat pencari informasi. Berikutnya, Gap terbesar adalah dimensi Responsiveness (daya tanggap), dan Emphaty (Empati) yaitu sebesar -0.5, artinya dimensi inilah yang 
menurut responden atau masyarakat pencari informasi belum mampu memenuhi kualias pelayanan sesuai dengan yang diharapkan oleh masyarakat tersebut.

\section{Analisa Fuzzy}

Logika fuzzy adalah konseptual yang mudah dipahami dan memiliki pendekatan alami. Logika fuzzy fleksibel dan dapat dengan mudah ditambah dan disesuaikan. Ada tiga komponen utama dari sistem fuzzy: set fuzzy, aturan fuzzy, dan bilangan fuzzy. Fuzzy set ini dikombinasikan dengan aturan-aturan fuzzy membangun sistem fuzzy, Komponen kedua dari sistem fuzzy adalah aturan fuzzy. Aturan fuzzy didasarkan pada pengetahuan manusia. (Giacheti, 2002).

Menurut Harto (2005), langkah yang dilakukan pada tahap ini adalah sebagai berikut:

\section{Fuzzification}

Terdapat dua variable input yaitu Persepsi dan Harapan. Masingmasing diberikan nilai dengan 5 parameter yaitu:

Tabel 3. Parameter Jawaban Variabel Input

\begin{tabular}{|l|c|}
\hline \multicolumn{1}{|c|}{ Kategori } & Skala \\
\hline $\begin{array}{l}\text { Sangat Penting (SP)/ Sangat } \\
\text { Puas (SP) }\end{array}$ & 5 \\
\hline Penting (P) / Puas (P) & 3 \\
\hline $\begin{array}{l}\text { Cukup Penting (CP)/ Cukup } \\
\text { Puas (CP) }\end{array}$ & 2 \\
\hline $\begin{array}{l}\text { Tidak Penting (TP)/ Tidak Puas } \\
\text { (TP) }\end{array}$ & 1 \\
\hline $\begin{array}{l}\text { Sangat Tidak Penting (STP)/ } \\
\text { Sangat Tidak Puas (STP) }\end{array}$ & \\
\hline
\end{tabular}

Sedangkan inferensi fuzzy Variable output yaitu kualitas pelayananyang menghasilkan output tingkat kualitas pelayanan, diberi nilai dengan 3 (tiga) parameter yaitu Tinggi (T), Sedang (S) dan Rendah (R).

\section{Inference}

Operator yang digunakan untuk menghubungkan antara dua input adalah $A N D$ dan yang menghubungkan antara input-output adalah IF-THEN. Berdasarkan data-data yang ada, dapat dibentuk 25 rule, beberapa diantaranya adalah sebagai berikut: 
1. If (Harapan is STP) and (Persepsi is STP) then (Pelayanan is $\mathrm{R}$ );

2. If (Harapan is $P$ ) and (Persepsi is $P$ ) then (Pelayanan is $T$ );

3. If (Harapan is $\mathrm{CP}$ ) and (Persepsi is $\mathrm{P})$ then (Pelayanan is $\mathrm{S}$ );

4. If (Harapan is SP) and (Persepsi is SP) then (Pelayanan is T)

3. Defuzzyfication

Penegasan (defuzzyfikasi) dilakukan dengan bantuan software MATLAB ToolBox Fuzzy. Berdasarkan data harapan dan persepsi yang diperoleh, hasil dari pengukuran tingkat kualitas pelayanan di bagian meja informasi Pengadilan Agama Kab. Kediri menggunakan pendekatan Metode Fuzzy Servqual, menghasilkan nilai seperti berikut:

Himpunan fuzzy untuk variable Harapan yang digambarkan dalam bentuk diagram membership function adalah seperti berikut:

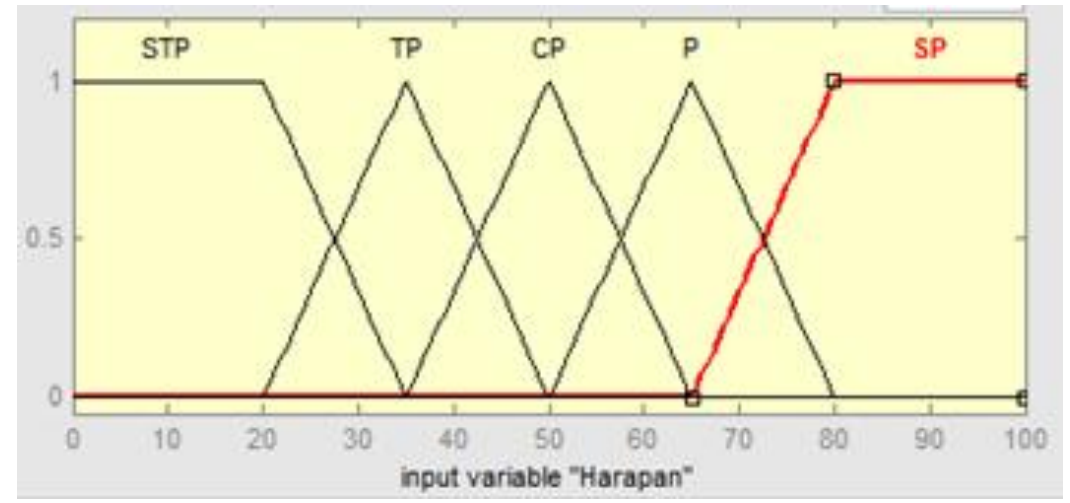

Gambar 2. Membership Function Variabel Harapan

Pada variabel harapan, data dibagi menjadi 5 himpunan fuzzy, yaitu sangat tidak penting, tidak penting, cukup penting, penting dan sangat penting. Himpunan fuzzy sangat tidak penting memiliki domain [0-35] dengan derajat keanggotaan tertinggi adalah 1 yang terletak pada nilai 20. Himpunan fuzzy tidak penting memiliki domain [20-50] dengan derajat keanggotaan tertinggi adalah 1 yang terletak pada nilai 35. Himpunan fuzzy cukup penting memiliki domain [35-65] dengan derajat keanggotaan tertinggi adalah 1 yang terletak pada nilai 50. Himpunan fuzzy penting memiliki domain [50-80] dengan derajat keanggotaan tertinggi adalah 1 yang terletak pada nilai 65. Himpunan fuzzy sangat penting memiliki domain [65-100] dengan derajat keanggotaan 
tertinggi adalah 1 yang terletak pada nilai 80. Apabila nilai variabel harapan semakin melebihi 20, maka nilainya semakin mendekati tidak penting.

Himpunan fuzzy untuk variable Persepsi ditunjukkan dengan diagram membership function adalah seperti berikut:

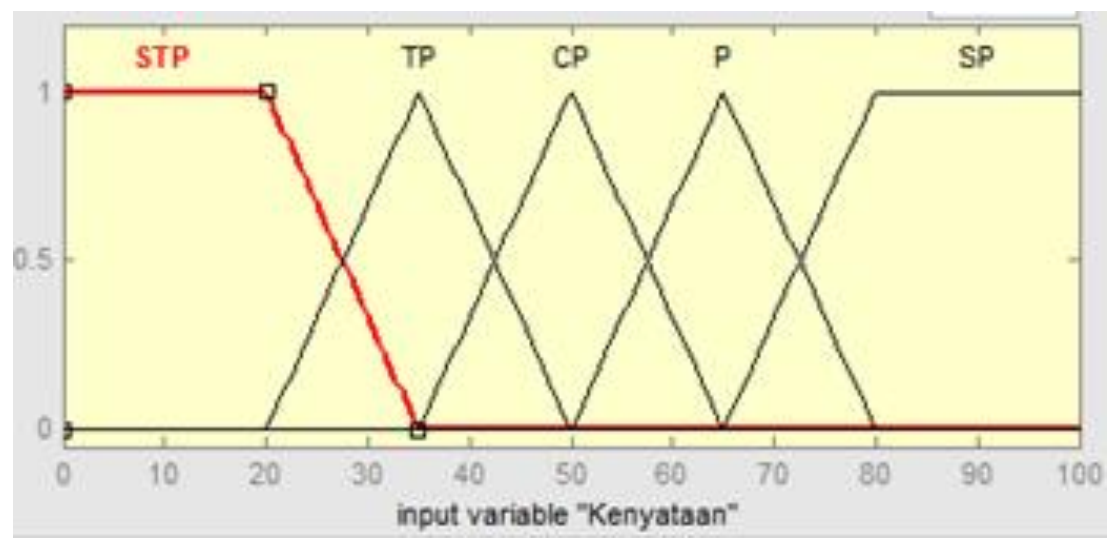

Gambar 3. Membership Function Variabel Persepsi/ Kenyataan

Pembentukan fungsi keanggotaan untuk himpunan Cukup Penting dan Penting adalah sebagai berikut:

Fungsi keanggotaan untuk himpunan cukup penting, dapat dilihat pada persamaan berikut:

$$
\mu C P_{\mathrm{IXd}}=\left\{\begin{array}{c}
0, X_{i} \leq 35 \text { atau } X_{i}>65 \\
\frac{\left(X_{0}-35\right)}{(50-35)} \quad ; 35 \leq X_{i} \leq 50 \\
\frac{\left(65-X_{0}\right)}{(65-50)} ; 50<X_{i}<65
\end{array}\right.
$$

Fungsi keanggotaan untuk himpunan penting, dapat dilihat pada persamaan berikut:

$$
\mu P_{X_{d} d}=\left\{\begin{array}{c}
0, X_{\mathrm{i}} \leq 50 \text { atau } X_{\mathrm{i}}>80 \\
\frac{\left(X_{0}-50\right)}{(65-50)} \quad ; 50 \leq X_{\mathrm{i}} \leq 65 \\
\frac{\left(80-X_{i}\right)}{(80-65)} ; 65 \leq X_{i} \leq 80
\end{array} ; 6\right.
$$


Variabel pelayanan adalah variabel output dengan tiga tingkat penilaian, randah, sedang dan tinggi. Penilaian variabel ini diperoleh dari hasil perhitungan terhadap dua variabel input yaitu harapan dan persepsi.

Diagram membership function untuk variabel pelayanan adalah seperti berikut:

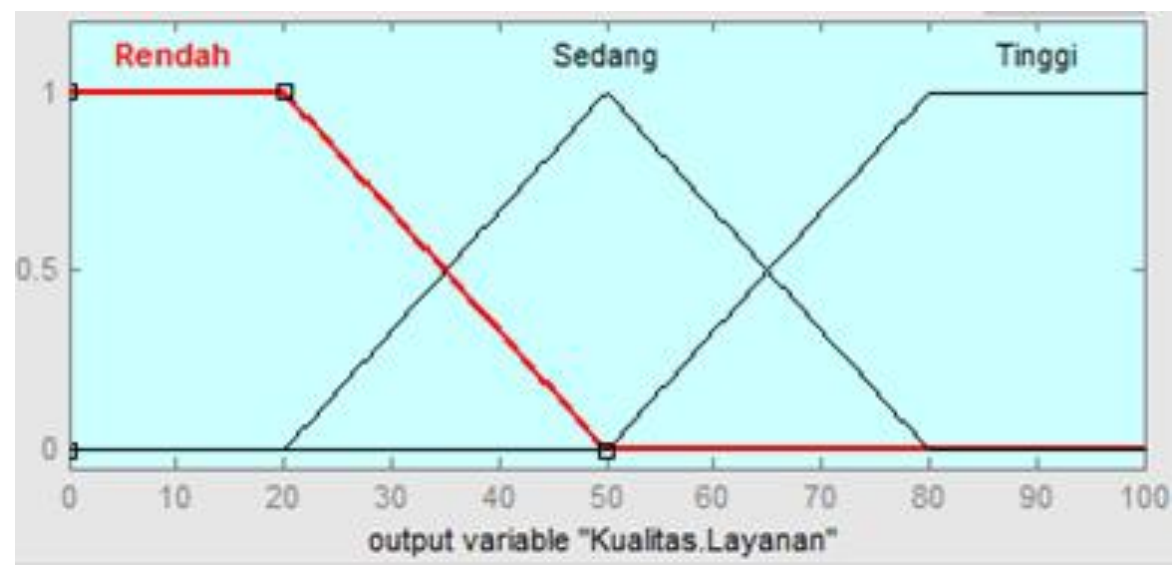

Gambar 4. Membership Function Variabel Pelayanan

\section{Pengolahan Fuzzy Servqual Dengan Fuzzy Logic ToolBox}

Berdasarkan data harapan dan persepsi yang diperoleh, hasil dari pengukuran tingkat kualitas pelayanan di bagian meja informasi Pengadilan Agama Kab. Kediri menggunakan pendekatan Metode Fuzzy Servqual, menghasilkan nilai bahwa secara keseluruhan pelayanan meja informasi (information desk) Pengadilan Agama Kab. Kediri selama ini dinilai baik, hal ini ditunjukkan oleh skor rata-rata nilai SERVQUAL yang diperoleh yaitu 78,56 dari rentang [0-100]. Namun dari data tersebut juga diperoleh informasi bahwa terdapat atribut-atribut pelayanan yang masih belum mampu memenuhi harapan masyarakat pencari informasi. Hal ini berarti harus ada upaya peningkatan pelayanan untuk lebih meningkatkan kualitas pelayanan meja informasi Pengadilan Agama Kab. Kediri agar mampu memenuhi keinginan dan harapan masyarakat.

Faktor-Faktor yang perlu ditingkatkan adalah pada dimensi Responsiveness (Daya Tanggap) yaitu dalam hal adanya perlu adanya sistem antrian meja informasi dan cepat tanggap petugas dalam memberikan pelayanan informasi. Petugas dalam memberikan informasi dan pada dimensi Emphaty 
(empati) utamanya dalam hal memberikan perhatian kepada masyarakat yang membutuhkan informasi, selain itu perlu pula ditingkatkan kemampuanPetugas dalam memahami dan memberikan informasi secara baik dan jelas.

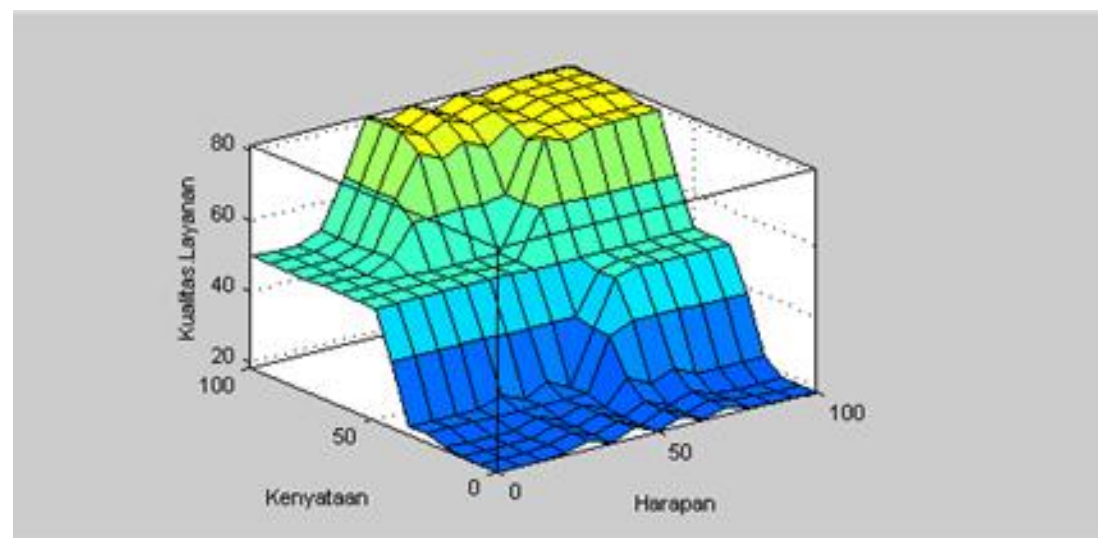

Gambar 5. Survace View Kualitas Pelayanan

\section{SIMPULAN}

Diperoleh kesimpulan bahwa Rata-rata penilaian masyarakat terhadap tingkat kepuasan masyarakat terhadap pelayanan yang diberikan meja informasi Pengadilan Agama Kabupaten Kediri telah memenuhi harapan masyarakat.namun ada beberapa faktor yang perlu lebih ditingkatkan lagi yaitu dalam hal perlu adanya sistem antrian meja informasi dan cepat tanggap petugas dalam memberikan pelayanan informasi. Perlunya memberikan perhatian kepada masyarakat yang membutuhkan informasi, selain itu perlu pula ditingkatkan kemampuan Petugas dalam memahami dan memberikan informasi secara baik dan jelas.

\section{DAFTAR PUSTAKA}

Parasuraman, A, Valarie A. Zeithaml and Leonard L. Berry Journal of Marketing Vol. 49, No. 4, pp. 41-50, A Conceptual Model of Service Quality and Its Implications for Future Research. Autumn, 1985.

Badan Peradilan Agama (2011). Surat Keputusan Direktur Jenderal Badan Peradilan Agama Mahkamah Agung Republik Indonesia Nomor:0017/DjA/SK/VII/2011 Tentang Pedoman Pelayanan Meja Informasi Di Lingkungan Peradilan Agama. Diakses tanggal 24 Januari 2017. Diakses dari http://badilag.net/suratkeputusan.

Harto, Budi. 2015. Analisis Tingkat Kepuasan Pelanggan Dengan Pendekatan Fuzzy Servqual Dalam Upaya Peninkatan Kualitas Pelayanan.Jurnal TEKNOIF Vol.3 No.1, April 2015. 
Kotler, Philip dan Kevin Lane Keller. 2008. Manajenen Pemasaran Jilid Dua. Indeks: Jakarta.

Lupiyoadi, Hamdani. 2006. Manajemen Pemasaran jasa. Edisi kedua. Jakarta: Salemba Empat.

Pengadilan Agama Kabupaten Kediri. 2015. Laporan Tahunan Pengadilan Agama Kab. Kediri Tahun 2015. Kediri: Author.

Puti, Widya Chitami. 2013. Pengaruh Kualitas Pelayanan dan Kepuasan Terhadap Loyalitas Pasien Rawat Jalan dan Rawat Inap Rumah Sakit Otorita Batam. Tugas Akhir: Universitas Widyatama Bandung.

Tjiptono, Fandy. 2005. Pemasaran Jasa. Yogyakarta: Bayu Media Publishing 